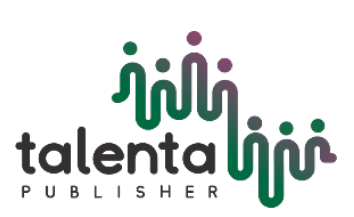

\title{
Chemical Compounds and Decomposition Process from Four Species Leaf Litter As a Source of Organic Matter Soil in Anggori Education Forest, Manokwari
}

\author{
Aditya Rahmadaniarti ${ }^{1}$ and Wolfram Y. Mofu ${ }^{1}$ \\ ${ }^{1}$ Faculty of Forestry, University of Papua, Manokwari 98314, West Papua Province, Indonesia
}

\begin{abstract}
Decomposition is a simple change of physical and chemical processes by soil microorganisms - the rate of decomposition process influenced by climate and litter quality factors. Litter content of chemical compounds is essential to determine the litter's quality to estimate the decomposition process. Leaves litter of Magnolia tsiampacca, Intsia bijuga, Cinnamomum cullilawan, and Aglaia sp., were collected and analyzed for their chemical compounds. Based on lignin and nitrogen content $(\mathrm{L} / \mathrm{N})$ value, Cinnamomum cullilawan has the fastest decomposition process. On the contrary, Intsia bijuga has low litter quality, so that has the slowest decomposition process. However, it has the lowest lignin content and high polyphenol content. Our research found that four observed species could be used as sources of soil organic matter, although the litter quality is relatively low.
\end{abstract}

Keyword: Chemical Contents, Decomposition, Leaf Litter

Received 15 November 2019 | Revised 2 July 2020 | Accepted 13 July 2020

\section{Introduction}

The decomposition of organic matter is an essential ecological process in a forest ecosystem. Litter falls on the ground and the nutrient content and releases back into the soil and available to plants through the decomposition process [1]. These nutrients cannot be directly absorbed by plants but need decomposition process first.

Buried soil organic matter from animals and plants in the soil is a target of soil organism absorption. It is converted into energy sources and tissue-forming materials from organic material (carbon). Since soil carbon source is in organic form, the amount of organic matter decomposition in the soil influences organic material. I mean that the organic matter decomposition rate depends on the content of decomposed organic material. Young plants commonly have a low $\mathrm{C} / \mathrm{N}$ ratio and tend to decay faster than organic materials or residual

\footnotetext{
*Corresponding author: Faculty of Forestry, University of Papua, Manokwari 98314, Indonesia E-mail address: a.rahmadaniarti@gmail.com
} 
materials with high lignin [2]. The litter decomposition rate is also one indicator of the rate of formed humus [3].

The contribution of organic matter to available plant form of nutrients depends on (1) the amount of organic material supplied, (2) nutrient content of organic matter, and (3) the rate of decomposition and mineralization. The rate of mineralization is considerably determined by organic material quality, such as nitrogen, polyphenols, lignin content, and other environmental factors [4]-[5]. The quality of organic matter is classified into high when it has high $\mathrm{N}$ content, low lignin, and low polyphenols content, so the nutrient releasing process becomes faster. On the contrary, organic matter quality is classified into low when the $\mathrm{N}$ content is small and high lignin and polyphenol contents. In this condition, the nutrient releasing process tends to be slow and takes time [6].

Two factors influence the litter decomposition process; those were climate and litter quality. Both elements are also supported by the presence of degraded organic matter microorganisms. The litter quality is determined by the content of compounds in the litter, such as carbon (C), nitrogen $(\mathrm{N})$, phosphorus $(\mathrm{P})$, lignin $(\mathrm{L})$, polyphenols. The quality showed by the ratio between these compounds' components, such as $\mathrm{C} / \mathrm{N}$ and $\mathrm{L} / \mathrm{N}$. Information about the chemical content of litter is essential to determine the quality of the litter. The better litter quality will be produced a faster decomposition process [7]-[9]. This study aims to determine chemical compounds content and estimate the decomposition process from leaf litter of Magnolia tsiampacca, Intsia bijuga, Cinnamomum cullilawan, and Aglaia sp. as a source of soil organic matter in Anggori Education Forest, Manokwari.

\section{Research Method}

The study was conducted at the Anggori Education Forest - Manokwari. Samples were obtained from 4 species (Magnolia tsiampacca, Intsia bijuga, Cinnamomum cullilawan, and Aglaia sp.) Where this species has been established in the Anggori Education Forest collection since 1962. The collection plot sample size of each stand was $50 \mathrm{~m}$ x $50 \mathrm{~m}$.

Leaf litter collection uses the $1 \mathrm{~m}$ x $1 \mathrm{~m}$ litter trap method, made from a plastic net with a 0.5 $\mathrm{mm}$ mesh. On every stand, five litter traps were placed with a height of $30 \mathrm{~cm}$ from the ground. Litter has been collecting and then air-dried and followed by drying in an oven at $80{ }^{\circ} \mathrm{C}$ for 24 hours. The litter then tested for its chemical content, including C, N, P, Lignin, Polyphenols, and Cellulose in Soil Science Laboratory, University of Brawijaya Malang.

\section{Results and Discussion}

The quality of organic matter determines the rate of decomposition of organic matter. The factor that determines the rate of decomposition in this study is the content of lignin or polyphenols. 
The content of the two compounds has a significant influence on the level of decomposition of organic matter. According to [5], the quality of organic matter includes the $\mathrm{C} / \mathrm{N}$ ratio, the content of lignin, polyphenols, and cellulose, determining whether or not a decomposed organic material. The quality of organic matter and the decomposition process's rate affect the formation of negative charges and the organic colloidal cation exchange capacity. Furthermore, according to [10], litter generally contains organic materials with different chemical structures, from simple chemical structures and relatively easy to undergo decomposition such as carbohydrates to carbon with complex chemical structures. It is difficult to undergo an overhaul process as lignin.

The higher lignin or polyphenol content will produce the lower $\mathrm{N}$ content in the decomposition process. Ultimately, the higher amount of $\mathrm{N}$ residue retained during the decomposition process so that less $\mathrm{N}$ is released. It is in line with [11], which states that polyphenols are parameters that could be used in estimating the rate of decomposition of tropical legume tree pruning. The litter quality analysis of Cinnamomum cullilawan leaf litter, Intsia bijuga, Magnolia tsiampacca, and Aglaia sp., are presented in Table 1.

Table 1 Chemical Compounds of Leaf Litter Cinnamomum cullilawan, Intsia bijuga, Magnolia tsiampacca, and Aglaia sp.

\begin{tabular}{lccccc}
\hline \multicolumn{1}{c}{ Type of Leaf Litter } & \% N Total & $\begin{array}{c}\text { \% } \\
\text { C-organic }\end{array}$ & C / N & $\begin{array}{c}\text { \% } \\
\text { Lignin }\end{array}$ & $\begin{array}{c}\text { \% } \\
\text { Polifenol }\end{array}$ \\
\hline Cinnamomum cullilawan & 1.73 & 41.81 & 24.17 & 26.24 & 3.12 \\
Intsia bijuga & 0.88 & 42.92 & 48.77 & 14.16 & 9.40 \\
Magnolia tsiampacca & 0.97 & 42.87 & 44.20 & 17.08 & 4.85 \\
Aglaia sp. & 1.40 & 45.61 & 19.44 & 27.22 & 7.74 \\
\hline
\end{tabular}

Based on Table 1, Cinnamomum cullilawan, Intsia bijuga, Aglaia sp, and Magnolia tsiampacca litter have different polyphenols lignin, $\mathrm{N}$-total, and $\mathrm{C}$-organic. The litter was classified as high quality if it has a $\mathrm{C} / \mathrm{N}$ ratio $<25$, lignin content $<15 \%$, and polyphenols $<4 \%$, so it decomposes quickly [11]-[12]. The quantified litter quality parameters were $\mathrm{N}$, lignin, polyphenol content, and $\mathrm{C} / \mathrm{N}$ ratio [5]. Therefore, the selection of plant species as sources of organic material is needed to determine the litter quality. 


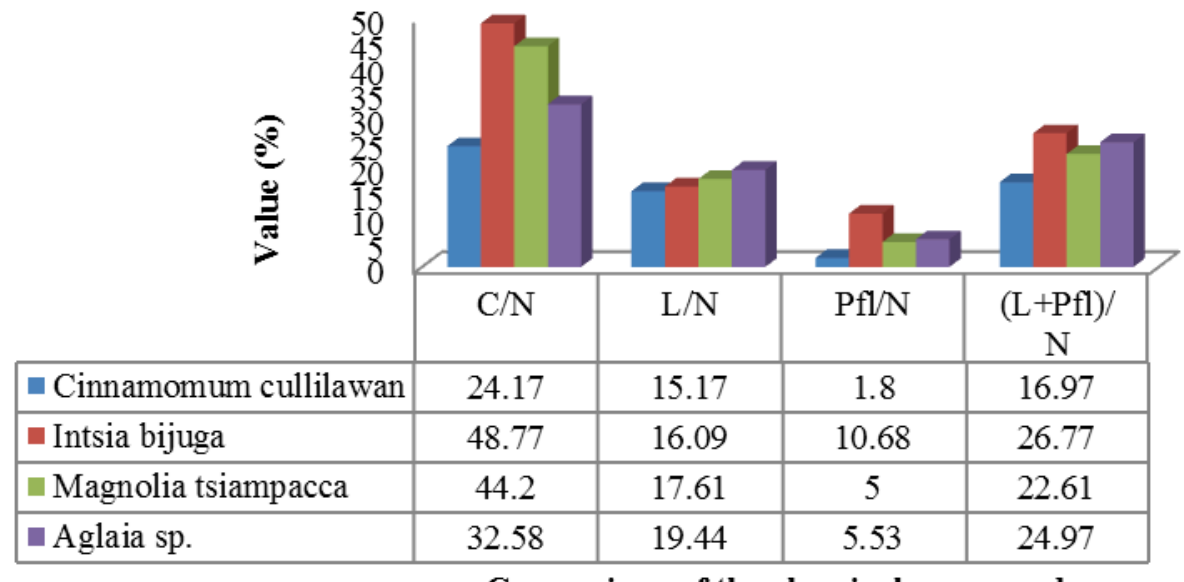

Comparison of the chemical compounds

Figure 1 Chemical compounds from leaf litter Cinnamomum cullilawan, Intsia bijuga, Magnolia tsiampacca, and Aglaia sp.

The $\mathrm{C} / \mathrm{N}$ ratio is one indicator to determine the level of decomposition. The speed of decomposition can observe from the decrease in the $\mathrm{C} / \mathrm{N}$ ratio. The $\mathrm{C} / \mathrm{N}$ ratio during the decomposition process can be used to reference the decomposition processes of sustainability. Factors that influence bacterial activity in the decomposition of plant organic matter are plant species and climate. Plant factors are usually in the form of leaves' physical and chemical properties, which are reflected in the ratio between carbon and nitrogen elements, which are expressed as the $\mathrm{C} / \mathrm{N}$ ratio [13]. Microorganism's diversity increase of effects the rate of the decomposition process and nutrient release patterns. During the decomposition process, the nitrogen content and the $\mathrm{C} / \mathrm{N}$ ratio in the substrate [14].

Figure 1 shows that the $\mathrm{C} / \mathrm{N}$ ratio values different for all four litter species. Cinnamomum cullilawan litter has a $\mathrm{C} / \mathrm{N}$ ratio value 24.17 , lower than the critical importance of the $\mathrm{C} / \mathrm{N}$ ratio $<25$ [10],[13], so the decomposition process was estimated to be faster. On the contrary, the C/N ratio of Intsia bijuga, Magnolia tsiampacca, and Aglaia sp. were very high, which is $>25$. The higher of the $\mathrm{C} / \mathrm{N}$ ratio value makes it challenging to litter to decompose. It is in line with [5], who reported that a $\mathrm{C} / \mathrm{N}$ ratio above 30 considered high, resulting in litter becoming more difficult to decompose. Furthermore, [15] stated that the optimum $\mathrm{C} / \mathrm{N}$ ratio for composting materials ranged from 30-40. The lower $\mathrm{C} / \mathrm{N}$ ratio value of the organic matter can make the shorter composting time. Based on the $\mathrm{C} / \mathrm{N}$ ratio, the decomposition process sequence is Cinnamomum cullilawan > Aglaia sp. > Magnolia tsiampacca $>$ Intsia bijuga.

The $\mathrm{C} / \mathrm{N}$ ratio is mostly determined by organic matter, which can be quickly influenced by decomposing microorganisms contained by organic matter [16]. Decomposition of organic matter microorganisms consisting of fungi and bacteria. Under aerobic conditions, bacteria will break down organic matter. When utilized organic matter content higher, the lower the $\mathrm{C} / \mathrm{N}$ ratio 
is faster. The rate of $\mathrm{C}$ decreasing was influenced by oxygen $\left(\mathrm{O}_{2}\right)$ or aeration content and the type of organic material.

Polyphenols and lignin are also essential parameters that affected the rate of litter decomposition. Polyphenols are compounds that can be used to determine the quality of plant residues and the rate of litter decomposition because polyphenols bind $\mathrm{N}$ in leaves to form compounds that are resistant to the decomposition process [6],[4],[10]-[11],[17]. Sources of organic matter are considered high quality if they contain polyphenols $<4 \%[10]$.

Based on leaf litter's polyphenols content, Cinnamomum cullilawan leaf litter could be classified into high quality because it contains polyphenols $<4 \%$. The high quality of Cinnamomum cullilawan and Magnolia tsiampacca litter shows the good organic material source, so it estimated that the decomposition process is faster than Intsia bijuga and Aglaia sp. Magnolia tsiampacca, Aglaia sp., and Intsia bijuga have the polyphenol contents more than $4 \%$. However, Magnolia tsiampacca polyphenol content is not too high, which is $4.85 \%$, while Aglaia sp. and Intsia bijuga have high polyphenol content; those were $7.74 \%$ and $9.40 \%$ (Figure 1). Based on the polyphenol's content, the decomposition rate is Cinnamomum cullilawan > Magnolia tsiampacca > Aglaia sp., > Intsia bijuga.

Lignin is a plant constituent that is difficult to decompose [18],[4],[19]-[20], and is one of the parameters in determining organic matter quality sources [18],[6],[19]. Cellulose and lignin are some of the criteria of fiber strength. The extraordinary mechanical properties of cellulose are strain, strength, and resistance to stress [21]. Natural lignin content can use to predict the rate of the decomposition process. The higher of lignin and cellulose content in the litter will produce the longer decomposes process. The decomposition process will be fast if the litter has lignin content $<15 \%$ [10], [22].

Intsia bijuga has the lowest lignin content compared to the other species; those was $14.16 \%$ $(<15 \%)$, so the decomposition process from the fastest is Intsia bijuga $>$ Magnolia tsiampacca $>$ Cinnamomum cullilawan > Aglaia sp. (Table 1). However, the lignin content only is not enough to get this prediction. So it needs to be compared with the content of other compounds, namely the Lignin to $\mathrm{N}$ ratio $(\mathrm{L} / \mathrm{N})$, Polyphenols to $\mathrm{N}$ ratio $(\mathrm{Pfl} / \mathrm{N})$, and (Lignin + Polyphenols) with $\mathrm{N}(\mathrm{L}+\mathrm{P}) / \mathrm{N})$. Based on the comparison of chemical compound values, Cinnamomum cullilawan has relatively lower $\mathrm{L} / \mathrm{N}, \mathrm{Pfl} / \mathrm{N}$, and $(\mathrm{L}+\mathrm{Pfl}) / \mathrm{N}$ values compared to the other. It can be predicted that Cinnamomum cullilawan will get a faster decomposition process. According to [23], the lignin/ $\mathrm{N}$ ratio is an excellent indicator to detect the level of mass loss. Besides, lignin also affects the enzymatic degradation of carbohydrates and proteins [24]. Based on the value of lignin and nitrogen content (L / N), it can be estimated that Cinnamomum cullilawan will have the fastest decomposition process. At the same time, Aglaia sp., will decompose at the latest. It 
can be described as Cinnamomum cullilawan $>$ Intsia bijuga $>$ Magnolia tsiampacca $>$ Aglaia sp.

According to [13], the $\mathrm{Pfl} / \mathrm{N}$ ratio of litter is the best parameter to estimate $\mathrm{N}$ mineralization rate from various tropical legumes with a critical value of 0.5 . However, [5] proved that the $\mathrm{Pfl} / \mathrm{N}$ ratio of legume plants is more than 0.5 , while the amount of $\mathrm{N}$ mineralization correlates more with the $(\mathrm{L}+\mathrm{Pfl}) / \mathrm{N}$ ratio than the $\mathrm{Pfl} / \mathrm{N}$ ratio. Conversely, if the organic matter has a high $\mathrm{N}$ content (low $\mathrm{C} / \mathrm{N}$ ratio) but high lignin, lignin will have more role in determining organic matter's decomposition rate. When the lignin content was high, and $\mathrm{N}$ or $\mathrm{C} / \mathrm{N}$ content is lower, it will produce a higher $\mathrm{N}$ from organic matter released slowly during decomposition. It may be due to the formation of N-lignin-derived compounds. Based on this statement, it showed that Cinnamomum cullilawan litter has the lowest value of the $\mathrm{Pfl} / \mathrm{N}$ ratio $(1.8)$ and $((\mathrm{L}+\mathrm{Pfl}) / \mathrm{N})$ $(16,97)$ then following Magnolia tsiampacca, Aglaia sp., and Intsia bijuga (Figure 1). It shows the critical role of the quality or composition of organic matter in influencing $\mathrm{N}$ released's amount and rate. Furthermore, [4] states that the $\mathrm{N}$ release rate from organic matter significantly correlated with $\mathrm{N}$, lignin, and polyphenol content. The rate of $\mathrm{N}$ release increases with increasing $\mathrm{N}$ content but decreases with increasing lignin and polyphenol content.

Returning plant biomass to the soil will improve the soil organic matter content. The process needs careful observation to synchronize the nutrient requirements for plants and nutrient release (through the mineralization process) from organic matter, bearing in mind that organic materials have different qualities. Often the release of $\mathrm{N}$ exceeds the needs of plants at the beginning of its growth so that plants do not absorb some $\mathrm{N}$. This condition will cause $\mathrm{N}$ lost by the leaching process. Excellent information on organic material management, primarily on litter quality, will produce good source organic material. One possible way is to choose quality organic matter for the soil or mix high-quality organic material with low-quality organic content.

\section{Conclusion}

Cinnamomum cullilawan has high litter quality and has the fastest decomposition process. In contrary to Intsia bijuga, it has low litter quality and estimated the slowest decomposition process. Our study points out that four observed species can be used as soil organic matter sources, although the litter quality is relatively low.

\section{REFERENCES}

[1] Prescott, C.E and R. Laiho, "Decay and Nutrient Dynamics of Coarse Woody Debris in Northern Coniferous Forest: A Synthesis," Canadian Journal of Forest Research, vol. 34, no. 4, pp. 763-777. 2004.

[2] Soedarsono, J., Mikrobiologi Tanah, Departemen Mikrobiologi Fakultas Pertanian University Gadjah Mada, Yogyakarta, p. 105 dan 140. 1981. 
[3] Hardiwinoto, S., Haryono, S., Fasis, M. dan Sambas S. "Pengaruh Sifat Kimia terhadap Tingkat Dekomposisi beberapa Jenis Daun Tanaman Hutan," Jurnal Manusia dan Lingkungan, Pusat Penelitian Lingkungan Hidup Universitas Gadjah Mada, vol. 4, no. 2, pp. 25-36. 1994.

[4] Tian, G, Kang, B. T, and Brussaard, L. "Biological Effects of Plant Residues with Contrasting Chemical Compositions Under Humid Tropical ConditionsDecomposition and Nutrient Release," Soil Biology and Biochemistry, no. 24, pp. 1051-1600. 1992.

[5] Handayanto, E., Cadisch, G., and Giller, K.E. "N Release from Legum Hedgerouw Tree Prunnings in Relation to Their Quality and Incubation Method," Plant and Soil no. 160, pp. 239-247. 1994.

[6] Young, A. "Agroforestry for Soil Conservation," CABI International, pp. 105-108. 1989.

[7] Hoorens, B., D. Coomes, and R. Aerts. "Neighbour Identity Hardly a Vects Litter Mixture Affects on Decomposition Rates of New Zealand Forest Species," Oecologia, no. 162, pp. 479-489. 2010.

[8] Kaushal, R, and K.S. Verma. "Leaf Litter Decomposition in Different Agroforestry Tree Species as Influenced by Climatic Variables and Substrate Quality," 2003. [Online]. Available: http://www.fao.org/3/XII/0464-B5.htm. [Accessed: Jul. 20, 2019].

[9] Muhammad, S., R.G. Joergensen, T. Mueller, and T.S. Muhammad, "Priming Mechanism: Soil Amended with Crop Residue," Pak. J. Bot., vol. 39, no. 4, pp. 1155-1160. 2007.

[10] Saidy, A. R. Bahan Organik Tanah: Klasifikasi, Fungsi dan Metode Studi, Lambung Mangkurat University Press. 2018.

[11] Palm, C.A., and P.A. Sanchez. "Nitrogen Release from Some Tropical Legume as Affected by Lignin and Polyphenol Contents," Soil Biol Biochem, no. 23, pp. 8388. 1991.

[12] Hairiah, K., Widianto, S.R, Utami, D. Suprayogo, Sunaryo, SM. Sitompul, B. Lusiana, R. Mulia, M. Van Noorwijk dan G. Cadisch. Pengelolaan Tanah Masam secara Biologi, International Centre for Research in Agroforestry (ICRAF), Bogor. 2000.

[13] Thaiutsa, B dan O. Granger. "Climate and Decomposition Rate of Tropical Forest Litter," UNASYLVA, no. 31, pp. 28-35. 1979.

[14] Iskandar, B. Dinamika Litterfall dan Kecepatan Dekomposisi Serasah pada Agroekosistem Perkebunan Karet di Kabupaten Dharmasraya, Skripsi Program Studi Agroteknologi Fakultas Pertanian Universitas Andalas, Padang. 2014.

[15] Suyanto, A dan A.T.P. Irianti. "Efektivitas Trichordema sp., dan Mikro Organisme Lokal (MOL) sebagai Dekomposer dalam Meningkatkan Kualitas Pupuk Organik Alami dari Beberapa Limbah Tanaman Pertanian,” Jurnal Agrosains, vol. 12, no. 2, pp. 1-7. 2015.

[16] Rao, N.S.S. Biofertilizer in Agriculture, Of Ford and IBH Publishing Co. New Delhi, Bombay, Calcuta. 1994.

[17] Hartemink, A.E., and J.N.O. Sullivan. "Leaf Litter Decomposition of Piper aduncum, Gliricidia sepium and Imperata cylindrical in the Humid Lowlands of Papua New Guinea," Plant and Soil, no. 230, pp. 115-124. 2001.

[18] Buckman, H.O and Brady, N.C. The Nature and Properties of Soil, The Mac Millan Company, New York. 1969.

[19] Handayanto, E., G. Cadish, and K.E. Giller, "Manipulation of Quality and Mineralization of Tropical Legume Tree Prunings by Verrying Nitrogen Supply," Plant and Soil, no. 176, pp. 149-160. 1995.

[20] Novizan, Petunjuk Pemupukan yang Efektif, Agromedia Pustaka, Jakarta. 2002.

[21] Fahn, A. Anatomi Tumbuhan, Penerjemah: Soediarto, A., Universitas Gadjah Mada Press, Yogyakarta. 1995.

[22] Rindiyastuti, R and A.S. Darmayanti, "Komposisi Kimia dan Estimasi Proses Dekomposisi Serasah 3 Spesies Familia Fabaceae di Kebun Raya Purwodadi," in Proceeding: Seminar Nasional Biologi, Fakultas Biologi UGM, Yogyakarta 24-25 September, 2010. 
[23] Bross, E., M.A. Gold and P.N. Nguyen, "Quality and Decomposition of Black locust (Ronina pseudoacacia) and Alfalfa (Medicago sativa) Mulch for Temperate Alley Cropping Systems," Agroforestry System, no. 29, pp. 255-264. 1995.

[24] Melillo, J.M., Naiman, R.J., Aber, J.P., and Linkis, A.E. "Factor Controlling Mass Lose and N Dynamic of Plant Litter Decaying in Northern Stream," Bull. Mar. Science, no. 35, pp. 341-356. 1984. 